STEVEN ROBINS

\title{
From "Rights" to "Ritual": AIDS Activism in South Africa
}

\begin{abstract}
In this article, I investigate how the moral politics of HIV/AIDS activism in South Africa is contributing toward new forms of citizenship that are concerned with both rights-based struggles and with creating collectively shared meanings of the extreme experiences of illness and stigmatization of individual HIVIAIDS sufferers. I argue that it is precisely the extremity of the "near death" experiences of full-blown AIDS, and the profound stigma and "social death" associated with the later stages of the disease, that produce the conditions for HIVIAIDS survivors' commitment to "new life" and social activism. It is the activist mediation and retelling of these traumatic experiences that facilitates HIVIAIDS activist commitment and grassroots mobilization. It is also the profound negativity of stigma and social death that animates the activist's construction of a new positive HIV-positive identity and understanding of what it means to be a citizen-activist and member of a social movement. [Keywords: social movements, AIDS, citizenship, ritual]
\end{abstract}

\section{INTRODUCTION}

The award-winning South African film Yesterday (2004) ${ }^{1}$ tells the story of a black woman with HIV/AIDS whose migrant miner husband returns from Gauteng to his home village in rural KwaZulu-Natal to prepare to die after having contracted HIV. Both the dying man and his wife are stigmatized and isolated by most of the villagers. ${ }^{2}$ The wife builds her dying husband a corrugated iron room on the border of the village so that he can live his last days away from the inquisitive and accusatory gazes of unsupportive villagers. Antiretroviral (ARV) therapy and the possibility of treatment appears nowhere in Darrell Roodt's moving portrait of this couple caught in whirlwind of this tragic pandemic. Yesterday reflects the grim realities of HIV/AIDS as the harbinger of social and biological death for millions on a continent in which most countries do not have national ARV treatment (ART) programs. South Africa now has an ARV program as well as a national HIV/AIDS social movement, which offers the prospect of a more optimistic script, one in which HIV-positive people are able to access lifeenhancing drugs that can return the patient to health and the possibility of reintegration into the social world.

In this article, I explore how the combination of illness experiences and enrollment in the Treatment Action Campaign (TAC) and Medecins sans Frontieres (MSF; or "Doctors Without Borders") treatment programs has, under certain circumstances, dramatically altered the lives, subjectivities, identities, life narratives, and futures of people living with HIV/AIDS (PWAs). It investigates these issues in the context of HIV/AIDS activist struggles for free treatment in South Africa's public health sector. Although these activist organizations are generally understood as rights-based social movements (Friedman and Mottiar 2004), the illness narratives and treatment testimonies that are analyzed in this article suggest that experiences of illness, treatment, and participation in TAC and MSF can produce radical transformations in subjectivity and identity that go well beyond conventional liberal democratic conceptions of "rights" and "citizenship." At the same time, these changes in subjectivity can, in certain cases, produce the kinds of "responsibilized citizens" that public health professionals believe are required for safe and effective AIDS treatment and drug adherence to take place.

There has been public debate in the South African media about the need to balance individual rights and responsibilities when it comes to HIV/AIDS. This is not surprising given the widespread fear that poor treatment adherence could produce multi-drug resistant HIV. Some public health professionals have sought to justify compulsory testing and status notification, and the overriding of individual rights to treatment for those who show signs that they may not be able to adhere to treatment (Cape Times 2006). For example, Professor Solly Benatar, the director of the Bioethics Centre at the University of Cape Town, recently called for a balance between the rights of individuals and the public health needs of society. To maximize adherence to ART, he argued, 
required that patients take some responsibility for their own health (Cape Times 2006). There have also been calls from progressive public health circles for a "new contract" between provider and client that would replace the paternalistic surveillance model of direct observation therapy tuberculosis (DOT-TB) treatment. The latter, it is argued, cannot work with lifelong ART, and what is needed are "responsibilized citizens" and knowledgeable and empowered HIVpositive clients. But how can these new rights and responsibilities approaches take hold in contexts characterized by extreme forms of HIV/AIDS stigma, shame, denial, and fear? What role should the state, public health practitioners, and civil society organizations play in fighting the HIV/AIDS pandemic in such contexts? What kinds of subjectivities; identities; and social, economic, and cultural conditions are necessary for safe and effective treatment of HIV/AIDS? These are some of the questions I raise in this study.

Drawing on illness narratives and treatment testimonies, I argue that these rights and responsibilities approaches do not adequately acknowledge the profoundly traumatic and transformative nature of illness and treatment experiences. ${ }^{3}$ Neither do they recognize the complex mix of religious, communal, biomedical, and activist mediations and narrations of illness and treatment experiences, and how these can contribute toward creating the kinds of "responsibilized citizens" that public health practitioners desire. Liberal individualist "rights talk," I argue, cannot grasp the radically transformative character of the new biosocial subjectivities and HIV-positive identities that I discuss in this article. The latter are not simply the product of liberal modernist discourses on the rights-bearing citizen. Instead, they are forged in course of the traumatic journeys from "near death" and "bare life" to "new life" that I refer to as rights passages.

\section{FROM “BARE LIFE" TO "NEW LIFE"}

Pain, illness, and suffering are often represented as inherently private and physical phenomena that have little to do with the social world. Yet numerous scholars have pointed out that the experience of pain and suffering is fundamentally social. For anthropologists this observation is neither new nor surprising. Writing in the 1960s, Victor Turner $(1961,1969)$ showed how Ndembu interpreted the sick individual body as a sign of disease and disorder in the wider social body; here, healing involved the realignment of the social. Biomedicine, by contrast, tends to depoliticize and individualize illness as well as contribute toward the formation of modern citizen-subjects. Paul Farmer is among a number of scholars who have interrogated biomedicine's depoliticizing and individualizing discourses by drawing attention to broader social, political, and economic structures that determine the epidemiological distribution and subjective experience of disease and suffering in the Third World. Farmer (2004) draws on the concept of "structural violence" to show how conditions of chronic poverty, gender inequality, and everyday violence limit the life choices of the HIVpositive poor women he encounters at his HIV/AIDS clinic in rural Haiti. These patients are the literal embodiment of global structures of inequality and structural violence.

Farmer's linking of the individual HIV/AIDS body to structural processes resembles anthropological accounts of how small-scale societies interpret the sick individual body as a sign of disease within a broader social body. South African HIV/AIDS activists belonging to the TAC and MSF make similar connections between individual PWAs and the body politic. Here, the wider social world is characterized by conditions of unequal and inadequate health care reproduced by the greed and profiteering of global pharmaceutical companies. These health inequalities are also understood by activists as the product of historical legacies of colonialism, apartheid, and (bio)capitalism as well as more recent forms of postcolonial state indifference and inaction in relation to the provision of HIV/AIDS treatment in the public sector (Robins 2004).

Hannah Arendt (1958) notes that the modern state had become increasingly concerned with biological existence and the management of "life processes." Similarly, Giorgio Agamben (1998) claims that both modern and archaic political orders have been preoccupied with the capacity to control life by excluding it from meaningful social and political existence. Drawing on the ideas of both Arendt and Agamben, Jean Comaroff argues that in the modern world the management and politics of "bare life" have shifted to center stage: It is both the object of state enforcement and the subject of projects of democratic emancipation and citizenship (Comaroff 2005:14). The political history of the West leads us to a situation whereby there is "an unprecedented capacity and concern to enhance life [that] is rivalled only by the power to destroy it" (Comaroff 2005:14). Comaroff reminds us that Agamben draws on homo sacer-the archaic Roman law figure who "could be killed but not sacrificed"-to illustrate that modern life is "simultaneously sacred, and utterly dispensable" (Comaroff 2005:15). Whereas Agamben is specifically concerned with the relation between homo sacer and sovereign power, Comaroff notes that scholars such as João Biehl (2001) and Ulrike Kistner (n.d.) are beginning to make the connection between this Roman law figure and "the Third World HIV/AIDS sufferer: a being condemned to callous exclusion, to death without meaning or sacrificial value, in an age of widespread humanitarian empathy; a being left untreated in an era of pharmacological salvation" (Comaroff 2005:15). Comaroff draws our attention to a moral politics of HIV/AIDS in places like Brazil and South Africa that insists on "making death sacrificial [and meaningful] once more" (Comaroff 2005:20). It is also a politics that is committed to making life-enhancing drugs available to millions of PWAs in the Third World.

In this article, I show how this new moral politics is constructed by HIV/AIDS activists and PWAs through the deployment of religious, communal, biomedical, and social activist discursive framings. PWAs often draw on these framings to make sense of their illness and social suffering. These framings, I argue, can contribute to the production of 
"positive" HIV-positive identities and new forms of sociality and solidarity for HIV/AIDS sufferers in Third World settings in which stigma and social isolation are pervasive and access to treatment continues to be a life-or-death struggle. They also suggest that conventional ways of thinking about rights, citizenship, and social movements are inadequate for understanding these processes associated with HIV and AIDS. The article makes two major interventions. First, I argue, drawing on the illness and treatment experiences of HIV/AIDS activists in South Africa, that social movements theory does not adequately address the complex and shifting subjectivities of individuals involved in HIV/AIDS activist movements. Second, I draw on Turner's analysis of ritual processes to understand how illness and treatment experiences can, together with forms of HIV/AIDS activism, contribute toward the production of new social subjects. I refer specifically to how South African HIV/AIDS activism has contributed toward such processes of social mobilization as well as new forms of "responsibilized citizenship."

South Africa now has one of the largest HIV/AIDS treatment programs in the world. Yet only approximately 60,000 of the estimated 600,000 people needing treatment are receiving ARVs through the public health sector, whereas another 45,000 are accessing treatment in the private sector (Cape Times 2006). This limited access to treatment is particularly worrying given current estimates that there are between five and six million HIV-positive South Africans. Notwithstanding the introduction of a massive national ARV program, HIV/AIDS activists find themselves having to continue to challenge the global pharmaceutical industry's patents policies and pricing structures, the national leadership's perceived lack of political will when it comes to treatment, and AIDS dissidents who persist in questioning the link between HIV and AIDS, the scale of the HIV/AIDS pandemic, and the efficacy and safety of ART (Robins 2004). In this article, however, I am concerned with another dimension of TAC activism-namely, its capacity to create the conditions for the production of new subjectivities and identities out of the traumatic experiences of illness and stigmatization of individual HIV/AIDS sufferers. I focus on the ways in which experiences of illness, treatment, and activism can together contribute toward profound changes in the lives of people with HIV/AIDS. In the following section, I discuss how I use Turner's pioneering work on the ritual process to interpret these illness and treatment experiences (Turner 1969). ${ }^{4}$

\section{REVISITING "THE RITUAL PROCESS": TREATMENT ACTIVISM AND "RESPONSIBILIZED CITIZENS"}

Turner's analysis of the ritual process provides a rich heuristic device and analytical lens through which to interpret how the extremity of "near death" experiences of full-blown AIDS, followed by "miraculous" recovery through ART, can produce the conditions for AIDS survivors' commitment to "new life" and social activism. It is the activist mediation and retelling of these traumatic experiences, I argue, that facilitates TAC's highly successful grassroots mobilizations.
I also argue that it is precisely these processes of illness, stigma, and treatment that provide activists with the "raw materials" with which to construct new HIV-positive identities and social solidarities.

These activist mediations of illness and treatment experiences can be distinguished from HIV/AIDS treatment in the public sector, which is shaped by the conventional doctor-patient dyad and highly technicist and depoliticized modes of biomedical intervention in the private spaces of doctors' consultancy rooms. By contrast, TAC activism creates the conditions for more collectivist responses to HIV/AIDS and treatment. Whereas public health practitioners report that most of their HIV/AIDS patients wish to retain anonymity and invisibility at all costs, TAC successfully advocates the transformation of the stigma of HIV/AIDS into a "badge of pride" that is publicly displayed on T-shirts at township funerals, demonstrations, workshops, and other public spaces. It is through these activist mediations that it becomes possible for the social reintegration and revitalization of large numbers of isolated and stigmatized HIV/AIDS sufferers into a social movement and a caring community. This HIV/AIDS activist culture has been very present at the two MSF-Department of Health ARV programs in Khayelitisha, Cape Town, and Lusikisiki, Eastern Cape Province. However, by far the majority of the public sector, ARV programs in South Africa are characterized by hierarchical and authoritarian doctor-nurse-patient interactions. Doctors and nursing staff working in these settings also believed that most of their HIV-positive patients would probably want to avoid involvement in HIV/AIDS activism precisely because of its emphasis on public visibility and disclosure (Dr. Ruth Cornick, personal correspondence, July 22, 2004). So what kinds of social and ritual processes can create the conditions for PWAs to turn HIV/AIDS stigma, isolation, and shame into a "badge of pride"?

\section{IDENTITY TRANSFORMATIONS AND TRANSITIONS: FROM ALCOHOLICS ANONYMOUS TO THE TAC}

In The Recovering Alcoholic, Norman K. Denzin draws attention to the role of Alcoholics Anonymous (AA) treatment rituals in "the transformations in experience that produce situational and long-term commitments to the identity of the 'recovering alcoholic' " (1987:12). Denzin describes these AA rituals as processes of "adult socialization" and "identity transformation or conversion," terms that "refer to the process by which the self of the person actively enters into the acquisition of new self-images, new languages of self, new relations with others, and new bonds or ties to the social order" (Denzin 1987:19). In his account of "the social worlds" of the recovering alcoholic, Denzin identifies the central role of AA rituals-the "Twelve Steps" and "Twelve Traditions" and rituals of storytelling —in the treatment and recovery process (1987:118-121). Although ritual may not appear at first glance to be a useful and appropriate concept for describing HIV/AIDS activism and social mobilization, in this article I draw on Turner's (1969) analysis of the ritual 
process to understand the extraordinary biosocial power of ART and HIV/AIDS activism in a context of "hyper-stigma" and HIV/AIDS traumas of social and biological death. I do so by analyzing the treatment narratives of two HIV/AIDS activists on lifelong ART. Discussion of these case studies rely on Turner's use of Arnold Van Gennep's (1960) identification of the three stages of rites of passage: separation, liminality/communitas, and reintegration. Ritual analysis offers analytical insights into the radical transformational power of these death-to-life transitions that PWAs personally experience, or witness. Turner's work can also throw light on the social status shifts that take place when the stigmatized and isolated sick recover and become reintegrated into TAC as healthy and socially active members of society.

Although it is problematic to generalize beyond these individual cases, I suggest that the two illness and treatment testimonies analyzed below do indeed resonate with narratives of HIV/AIDS experience that are widely shared and circulated within TAC. These narratives have become part of the collective cultural repertoire of TAC even though not all members have personally been through these illness and treatment experiences. Although HIV/AIDS activists may not frame illness and treatment experiences through ritual analysis, it would seem that the transformations and transitions from "near death" to "new life" can be illuminated through the analytical heuristic of rights of passage. But what is the nature of these transformations and how do we relate these to questions of citizenship and subjectivity?

\section{AIDS ACTIVISM AND BIOLOGICAL CITIZENSHIP}

Elsewhere, I have written about the extraordinary activism that has accompanied the struggles for access to ART in South Africa (Robins 2004). TAC and MSF have been at the forefront of this global and grassroots struggle for treatment. HIV/AIDS activists have used the courts, mass action, the mass media, the Internet, and grassroots mobilization to challenge drug patent policies and pricing structures of the global pharmaceutical industry as well as contesting AIDS dissident science and pressuring the South African government to provide ARVs.

HIV/AIDS activism in South Africa shares similarities with identity-based illness movements elsewhere in the world (Epstein 1996; Petryna 2002). Concepts such as "biological citizenship" (Petryna 2002) speak to a range of illness-based movements that have mobilized around nuclear radiation, breast cancer, psychiatric illnesses, and HIV/AIDS. "Lay expertification" (Epstein 1996) and "citizen science" (Irwin 1995) are increasingly used to describe citizen responses to unpredictable and poorly managed health and environmental hazards. These developments, which often result in citizen skepticism and distrust of mainstream science and expertise, are linked to what Ulrich Beck (1992) and Anthony Giddens (1991) refer to as contemporary conditions of reflexive modernity and "world risk society." For Beck and Giddens, both of whom are writing specifically about the advanced capitalist countries of the West, citizens have become increasingly distrustful of scientists and the scientific findings produced by governments and business. It is within this context that citizen science movements and new forms of biological and health citizenship are emerging. These processes intersect with the popular fascination - at least in the United States and Europe-with "risk factor" epidemiology, a technicist discourse that involves ever-finer calibration and endless attempts to control risk in every aspect of our lives (Chris Colvin, personal correspondence, June 25, 2004).

TAC and MSF activists argue that they are not only interested in medical treatment but also concerned with creating "empowered citizens" who understand the connections between biomedicine, the wider social world, and the political economy of health. This is evident in their legal challenges to the drug patents and pricing structures of the global pharmaceutical companies (Robins 2004). TAC activists also share similar concerns with the northern illness-based movements that have emerged as a result of citizen perceptions of inadequate scientific and government responses to a range of health and environmental hazards-for example, bovine spongiform encephalopathy (BSE; or mad cow's disease), foot and mouth disease, biotechnology and genetically modified organisms (GMOs), pesticides, HIV/AIDS, global warming, and so on. TAC also has its roots in distrust of government's response to the pandemic, especially President Mbeki's flirtation with HIV/AIDS dissident science and his government's initial reluctance to provide ARVs. It is this broad range of health and environmental concerns that are driving the growth of illness-based social movements such as TAC.

\section{TREATMENT ACTION CAMPAIGN}

TAC $^{5}$ was established on December 10, 1998, International Human Rights Day, when a group of about 15 people protested on the steps of St. George's Cathedral in Cape Town to demand medical treatment for people living with the virus that causes AIDS. By the end of the day, the protestors had collected over a thousand signatures calling on the government to develop a treatment plan for all PWAs.

TAC's membership has grown dramatically over the past few years. The rank-and-file comprises mainly young urban working-class African women with secondary schooling. Most of these volunteer members are either HIVpositive or they have family members and friends who have died of AIDS complications or are living with HIV. However, the organization has also managed to attract health professionals and university students. The international face of the organization is Zackie Achmat, a forty-something Muslim man who is both a gay activist and former antiapartheid activist. Until very recently, Achmat had made it known publicly that he refused to take ARVs until they were available in the public health sector. Other TAC leaders include 
African men and women who joined TAC as volunteers and moved into leadership positions over time.

When TAC was founded, it was generally assumed that anti-AIDS drugs were beyond the reach of developing countries, condemning 90 percent of the world's HIV-positive population to a painful and inevitable death. Although TAC's main objective has been to lobby and pressure the South African government to provide HIV/AIDS treatment, it has been forced to address a much wider range of issues. These include tackling the global pharmaceutical industry in the media, the courts, and the streets; fighting discrimination against HIV-positive people in schools, hospitals, and at the workplace; challenging AIDS dissident science; and taking the government to court for refusing to provide ART, including prevention of mother-to-child-transmission (PMTCT) programs in public health facilities (Robins 2004; Cameron 2005). TAC's highly effective mobilization at the global scale and within working-class black communities enabled it to challenge both "Big Pharma" drug pricing and patents policies and the South African government's initial refusal to provide ARVs to the poor in public health facilities (Robins 2004). It has also worked in partnership with MSF at two highly successful ART programs in Khayelitsha, Cape Town, and Lusikisiki, Eastern Cape Province. Elsewhere, I have discussed in some depth the nature and extent of TAC and MSF activism and the politicization of AIDS science, treatment, and statistics in South Africa (Robins 2004). Rather than revisiting these issues, I turn in the following section to an analysis of the illness narratives and treatment testimonies of two TAC and MSF HIV/AIDS activists.

\section{"AIDS IS IN MY BLOOD": ILLNESS NARRATIVES AND TREATMENT TESTIMONIES}

\section{"AIDS Has Been a 'Blessing in Disguise""}

Thembeka is a thirty-something HIV-positive TAC activist in Lusikisiki, a small rural town in the former Transkei homeland in the Eastern Cape. She told me that discovering her HIV status and joining TAC and the MSF ART program had dramatically improved her life: "Thanks to TAC and MSF I'm flying. I've got wings to fly" (conversation with author, April 22, 2004). I recall being shocked when Thembeka first described her experience of HIV as a "blessing in disguise." Yet, as I got to know her, it became clear that being tested for HIV and joining TAC and the MSF ARV program in Lusikisiki had indeed ushered in for her a new and better life. She recalled the trauma of sexual abuse by an uncle as a young girl and then being sent away to stay with her mother's friends as a teenager while her younger sister stayed at home and attended a good school. She also tearfully recollected a violent gang rape by four youths and being unable to tell her parents about it because she feared that they would not believe her. Her rape led to pregnancy and her decision to have an abortion, whereas her later discovery of her HIV status led to her decision to have a sterilization operation.

After I had my VCT [Voluntary Counseling and Testing] the Counsellor told me that I'm HIV positive and that all my dreams are finished and I'm going to just die. And then they told me that all my kids would be HIV-positive. It's either I'll condomize, or if my husband sometimes doesn't want to use condoms then I should just use sterilization. That's the way that can help me. Because the more babies I have the more quickly I will die. [conversation with author, April 22, 2004]

Thembeka's life story included accounts of child sexual abuse, rape, abortion, sterilization, and the onset of serious debilitating illness, culminating in her discovery in 2001 that both she and her baby were HIV-positive: "I was very sick but then I found TAC and MSF and my life changed. ...TAC is my mother, MSF is my father" (conversation with author, April 22, 2004). Although her mother, who was a nurse, subscribed to the minister of health's controversial nutritional diet of garlic, lemons, olive oil, and the "African potato" for HIV-positive people, Thembeka's involvement with MSF and TAC led to her rejection of these "alternative" and "traditional" remedies and her participation in ART at the MSF program in Lusikisiki. The health minister's promotion of this "nutritional advice" was interpreted by HIV/AIDS activists such as Thembeka as tacit support for the dissidents' claims that ARVs were dangerously toxic (Robins 2004). Yet during an earlier spell of illness arising from opportunistic infections, and at the same time that her mother was giving her "traditional" medicines, Thembeka was receiving allopathic medicines from an uncle, who happened to be a senior official in the national department of health. As her health improved under ART, Thembeka became integrated into the closely knit and supportive network of TAC activists and MSF doctors and nurses. She learned HIV/AIDS-awareness training skills and acquired basic scientific knowledge about HIV/AIDS, prevention, and treatment. She was also personally handed her ARVs by former President Nelson Mandela when he officially launched the ARV program in Lusikisiki in 2003. When I met her in 2004, she was being "headhunted" by nongovernmental organizations (NGOs) in the Eastern Cape but had decided to stay on as an MSF treatment literacy practitioner (TLP) and youth organizer in Lusikisiki. She spoke about her work as "preaching the gospel." The following account of illness and treatment shares some of the aspects of Thembeka's experience.

\section{"I Am Like a Born Again, ARVs Are Now My Life"}

Sipho, an activist living with HIV/AIDS, is in his early forties. He became desperately ill. He had headaches, dizziness, and suffered from a range of other opportunistic infections, he had lost almost 30 kilograms (66.14 lbs.), his CD4 count was down to 110 , his viral load was 710,000 , he could not walk, he was barely conscious at times, and he secluded himself in a room in his sister's house waiting for death. On November 12, 2001, he became one of the first 50 clients to participate in MSF's ART program in Khayelitsha. His recovery was dramatic: After six months his viral load had dropped to 215,000, his CD4 went up, and he was feeling much stronger. When I met Sipho in 2004, his viral 
load was undetectable and his CD4 count was $584 .{ }^{6}$ He had also become something of an HIV/AIDS celebrity and was also regularly interviewed by journalists, filmmakers, and academics about his experiences-for instance, he had represented South Africa at a Southern African Development Community (SADC) meeting in Lesotho on HIV/AIDS, and he was in demand from medical and social science researchers involved in HIV/AIDS research projects.

At the time of writing this article, Sipho was working at a private health insurance company where he telecounseled HIV-positive clients who were referred to the call center by general practitioners who had detected treatment adherence and related problems. As a result of requests from some clients for face-to-face meetings, Sipho sometimes visited them at their homes. Even though the call center was established to create the conditions of anonymity and confidentiality, Sipho's own seropositive status and his highly personal style of telecounseling elicited requests for more personal forms of interaction. As a result he spent many weekends visiting PWAs in Cape Town and elsewhere in the country. As he put it, "I am committed to my AIDS work. AIDS is in my blood" (conversation with author, March 26, 2005). Telecounseling could not adequately meet his own needs for more personal face-to-face interactions.

Clinical indicators such as "normal" CD4 counts and "undetectable viral loads" do not adequately convey the sense of social, psychological, and spiritual recovery that Sipho and others have experienced on their journeys from "near death" to "new life." Neither do these indicators account for why Sipho, like Thembeka, viewed HIV/AIDS as "a blessing in disguise." For Sipho, getting his life back through ART was a gift from God that he could not afford to squander:

I'm not a church-goer. My faith comes from the time I got sick. ... In the Bible there is the story of a sick beggar on the road. Jesus comes by and tells the beggar to stand up. And he stands up. The miracle of Jesus revived him from death so that he could heal other people through the belief that Jesus is on earth. Faith is in yourself. If you don't believe in yourself, who do you believe in? God brought me back to life for a purpose. He wants me to go out there and talk to people. He's giving me another chance. A day could cost me a lot if I don't speak about HIV. ... At Groote Schuur [Hospital] I prayed a lot. I was thinking of my children growing up without their father's love, support, and guidance. ...I am like a born again. ARVs, that's where my commitment comes from. It's like committing yourself to life because the drugs are a life time thing. ARVs are now my life. [conversation with author, March 26, 2004]

At the 2003 TAC national conference in Durban, I witnessed a particularly powerful session in which members gave impromptu testimony of their treatment experiences. Each highly charged testimony was followed by outbursts of song, dance, and struggle chants: "Long live, Zackie, long live. Long live, TAC, long live!"

I'm a person living with HIV. I received counselling before and after I tested. The counsellors at the hospital where I work as an admin clerk gave me nothing. I just found out
I was HIV-positive and that was that. Three times I tried to commit suicide. Now I'm more positive than HIV-positive, thanks to TAC. [a thirty-something black man]

When I go to my doctor, I tell him exactly what medicines I need. He asks me if I've trained in medicine at the university. No, I say to him. It was TAC that taught me. [a thirty-something black woman]

Thank you to MSF. My CD4 count was 28 now it is 543. Thank you to TAC. [a twenty-something black man]

I'm Dudu. I was tested in 1986. In 1999 my CD4 count was below 200. I have lost many things in my life. But now with ARVs my CD4 count is 725 and the virus is undetected. I'm a person living with HIV. Today I have a life. I can have a family. But it's painful when I take my medicine [ARVs] because I know someone is dying because he can't get treatment. [a twenty-something black man]

These treatment testimonies-with their references to CD4 counts, viral loads, and the role of TAC in giving "new life"-seem to blur the lines between science and religion, medicine and spirituality, and technology and magic. The quasi-religious quality of these testimonies is particularly evident in the excerpt from Sipho's testimony, which was cited earlier. The testimonies seem to implode efforts to erect an artificial "Great Divide" between "the modern" and "the traditional" (Latour 1993). They also express the sense of personal empowerment that comes from having survived the passage from "near death" to recovery. This was evident during Sipho's testimony at the Durban meeting in 2003:

I'm Sipho from Cape Town in the Western Cape. I was diagnosed in 2001, three days after my birthday. I was very sick. When you get sick you just ignore it. You say, "Oh, it's just the flu." You're in the denial stage. You say your neighbour is a witch. ... We thought this disease belonged to other people elsewhere in Africa. From my point of view HIV is real, it's here. I never thought I would be here today. I couldn't stand, I was sick. My CD4 count was 110 and my viral load was 710,000. Then I started ARVs with MSF in Khayelitsha. Now I'm strong. [testimony given at Durban TAC Congress 2003]

Sipho's statement "AIDS is in my blood," noted earlier, signifies both a scientific statement about HIV/AIDS infection as well as a metaphorical statement about "who I am and what my purpose is." This symbolically charged language captures the extraordinary agency and sense of purpose that Sipho and many other activists living with HIV/AIDS seem to share.

The following section analyzes these treatment testimonies and narratives by drawing on Turner's method of ritual analysis. Ritual analysis of illness and treatment experiences, I argue, is able to transcend the limits of social movements theory with its focus on "rational" and instrumental behavior and political processes of mobilization. An analysis of ritual processes can enrich this theoretical approach by drawing attention to the salience of processes of personal transformation and how these articulate with collective beliefs and mobilization practices. Conventional social movements theory tends to assume an already existing, stable, and coherent activist subjectivity, and that members 
simply need to be "invited" to participate in an already existing organizational structure built on shared interests.

\section{DISCUSSION OF THE TREATMENT TESTIMONIES: THE RITUAL PROCESS REVISITED}

Turner's The Ritual Process (1969) identifies three stages of rites de passage - separation, liminality/communitas, and reintegration. It would seem possible, based on the treatment narratives discussed earlier, that the extremity of the forms of stigma, ostracization, and isolation that PWAs experience are analogous to the stage of "ritualized separation" identified by Turner. During this first stage, the individual becomes sick, is afflicted with opportunistic infections, and may already be in an advanced stage of AIDS. The illness may be understood by sick persons, family members, and neighbors to be the work of abathakathi (witchcraft), a sign of having been chosen by the ancestors to be a sangoma (traditional healer or diviner), or simply an "ordinary" illness such as "flu" or tuberculosis. Alternatively, the onset of these illnesses may lead to testing and the confirmation of an HIV-positive status. This extreme state of illness often results in the withdrawal of the sick person from everyday social spaces (see Sipho's illness narrative). The "smell of death" may also heighten stigmatization, ritualized avoidance, and social and physical isolation by neighbors and family members. For example, "Nomsa," a 20-year-old HIVpositive woman I met in Lusikisiki in the Eastern Cape Province, spoke of how, on disclosing her HIV-positive status to her family, she was given her own plates and utensils to eat with. Thereafter her stepfather chased her from his home and she moved to her mother's home.

Isolation is also produced by the illness itself. An HIV/AIDS clinician who works at an ARV rollout site in Cape Town tried to explain to me the obstacles to communicating with patients with full-blown AIDS. "They are so sick that it is often very difficult to have a conversation with them. They are sometimes like walking skeletons" (conversation with author, August 24, 2004). This exceptionally dedicated and committed HIV/AIDS clinician talks of being unable to socially interact with these skeletal-like patients; at this advanced stage of AIDS, they were like the "walking dead," almost completely cut off from sociality. These descriptions are strikingly similar to the musselmans of the concentration camps that Primo Levi wrote about in The Drowned and the Saved (1979).

In the second phase, the sick person may seek biomedical treatment of opportunistic infections, join a TAC support group, and enroll, depending on clinical indicators, for ART. The patient-activist learns basic scientific and biomedical knowledge about HIV/AIDS, including its symptoms and ART. During this stage, patients are in a state of liminality as their future health status remains precarious and uncertain. They are "betwixt and between" in that it is not clear whether they are dying or on the path to recovery and health. They may have to wait to find out whether the drugs will work and whether there will be seri- ous side effects. Meanwhile, recruitment into TAC allows them access to a supportive community and nonhierarchical social space that is analogous to the experience of communitas that Turner describes as characterizing states of "liminality."

Finally, the recovery of the patient-activist with HIV/AIDS can be likened to Turner's third phase of "reincorporation." In this third stage, the individual starts getting physically and psychologically well, the CD4 count increases, the viral load drops, and the person begins putting on weight and rediscovers his or her appetite for food, sex, and sociality. This phase usually involves social incorporation into the TAC and possibly also the wider community and society. It can transform the stigmatized and dying AIDS sufferer into an activist-citizen empowered with knowledge about HIV/AIDS and an ability to speak out in public spaces. Of course, there is no inexorable linear treatment trajectory, and rejection and expulsion from community cannot be excluded as a possible treatment outcome. For Sipho and Thembeka, however, this phase culminated in personal empowerment and spiritual awakening that convinced them "HIV is a blessing in disguise." TAC members with HIV/AIDS are hereby reinstated into the social world as human beings with dignity; they have a new positive HIV-positive status. In the case of Sipho and Thembeka, it was clear this process of social reintegration also involved a commitment to a "new life" and social activism. This is what I mean by the biosocial passage from "near death" to "new life."

Although there are clearly dangers in seeking too tight a fit between Turner's model of the ritual process and the actual experiences and subjectivities of patient-activists with HIV/AIDS, this approach can account for why ART and TAC mobilization appears to have been so successful at reconfiguring the stigma, isolation, and suffering of AIDS into a positive and life-affirming HIV-positive identity and quasireligious commitment to "new life" and social activism.

Revisiting Turner's The Ritual Process (1969) can provide other important insights that have been ignored by theorists of both "old" and "new" social movements. For example, Turner finds common themes and structural features in millenarian religious movements, hippies, and Franciscans; all these movements comprise marginal, or selfmarginalized, people who are committed to the eradication of distinctions based on inequality and property. They are dedicated to the leveling of status and a communitarian ethos of unselfish commitment to collectively shared ideals. According to Turner, these movements strive to instantiate a permanent state of liminality and communitas-a statusless egalitarianism-not that different from the middle passage of "traditional" rites of passage.

Like the social groups identified by Turnermillenarians, hippies, and Franciscans-TAC consists largely of "social marginals": specifically, the sick and stigmatized poor, especially young unemployed black women. It is not surprising that this social category of "marginals" would be drawn to a social movement that 
strives to eradicate distinctions based on status and hierarchy. These women are either HIV-positive themselves or have family members who have been deeply affected by the epidemic. They are also in many instances members of a generation that the liberation struggle has left behind. Unlike the high profile antiapartheid activists of the 1980s, the majority of whom are now in government or business, TAC's rank-and-file members are generally without jobs and career prospects. This postrevolutionary generation of young people are caught in liminal space--"betwixt and between" structural marginalization and the dream of postapartheid liberation. Many of them do not have the material means, education, or cultural capital to move beyond this structural location of marginality and liminality. In addition, they face the very real threat of social and biological death from AIDS, making it unlikely that they will be able to move through the life cycle rituals and trajectories of personhood of their parents' generation. In other words, this social category is caught in the zone of liminality and the shadow of death. What happens when the transition from youth to adulthood and elder status is blocked by structural unemployment and the lethal equation: sex = death? How is it possible to participate in social and biological reproduction and life cycle rituals given such life-threatening circumstances? It is here, in the shadow of social and biological death, that the combination of ARVs and TAC activism offers such a compelling possibility for "new life."

\section{THE LIMITS OF SOCIAL MOVEMENT THEORIES}

In recent decades there has been a proliferation of studies celebrating the spectacular growth of globally connected social movements from Seattle to Johannesburg (see Cohen and Rai 2000). Marc Edelman (2001:285), in an extensive review of the social movements literature, notes that theories of collective action have undergone a number of paradigm shifts from "mass behavior" to "resource mobilization," "political process," and "new social movements." Edelman identifies these paradigm shifts with four major theoretical approaches to understanding collective action in the 20th century and draws attention to the conceptual limits of these theories. First, "functionalist frameworks" (Smelser 1962) viewed collective behavior as irrational mass responses to societal breakdown but could not explain events such as the counterculture hippy movements of the 1960s that took place amidst almost unprecedented North American affluence and political stability. Second, "rational actor approaches" (Olson 1965) understood social movements as the sum of participants' strategic individually oriented choices but could not account for seemingly sacrificial or altruistic life choices and forms of political participation-for example, the decisions taken by $1960 \mathrm{~s}$ students in Europe and North America to "drop out" of middle-class career trajectories. Third, "traditional Marxist approaches" viewed the bourgeoisie and the proletariat as the central antagonists in capitalist societies, yet it became clear that many of these social movements had leaders from middle-class backgrounds and had multiclass constituencies. In addition, Marxist approaches were perceived to be unable to adequately address a range of concerns relating to gender, sexuality, race, ethnicity, culture, nationalism, and so on. In the 1970s, theorists of new social movements sought to address these conceptual conundrums and theoretical blindspots.

Alain Touraine $(1981,1985)$ was one of the first scholars to theorize the emergence in Europe in the 1970s and 1980s of the new environmentalist, peace and antinuclear, womens', gay liberation, minority rights, and student and youth movements (see also Melucci 1989). Since then, the list of new movements has grown to include struggles for human rights and democratization, the rights of indigenous peoples, and the needs of the rural landless and urban slum dwellers. Attempts to classify these movements resulted in the category of "old" social movements being assigned to movements concerned with labor struggles in terms of which class was the central social divide, category of analysis, principle of organization, and political issue (Edelman 1999:417). The "new" movements, by contrast, rejected class as the master category and sought to achieve their goals outside of existing institutional channels and party political structures. These new movements were more concerned with questions of "cultural struggles" over meanings, symbols, collective identities, and rights to difference (Alvarez et al. 1998; Escobar and Alvarez 1992). ${ }^{7}$ Poststructuralist theorists also drew attention to social movement participants' multiple social positions and complex motivations for participation that could not be derived from a single principle of identity or a particular structurally defined material interest (Laclau and Mouffe 1985:27). Although theorists such as Laclau and Mouffe have provided important theoretical insights into these new social movements, there have been very few ethnographic studies of the actual processes of subject and identity formation that these movements entailed.

Scholars working within science and technology studies (STS) have extended the scope of the social movements literature by addressing new forms of citizen participation and social mobilization in the fields of biotechnology, biomedicine, environmental activism, and so on (Epstein 1996; Leach et al. 2005). This new direction in science studies also intersects with a growing literature that focuses on the diverse ways in which biomedical technologies are radically constituting new subjectivities and forms of citizenship (see Biehl 2001, 2004; Nguyen 2005; Petryna 2002; Robins 2005a, 2005b, 2005c). In this article, I have focused specifically on the ways in which treatment activism and the introduction of ART within the public health system have transformed subjectivities and contributed toward the emergence of a new HIV/AIDS activist movement in South Africa.

Conventional social movement theory cannot adequately account for how the structural conditions of marginality, the political culture of the antiapartheid 
struggle, and experiences of illness and treatment have contributed toward the formation and everyday practices of organizations such as TAC. Neither can these theories adequately account for how the illness experiences and "spoiled identities" associated with AIDS stigma, denial, and discrimination are reconfigured and transformed by TAC activists into a "badge of pride," a new HIV-positive identity and form of social belonging. This new identity, I suggest, cannot be understood simply in terms of the instrumentalist logic of political and economic struggles for access to health resources. Neither is this struggle for recognition and human dignity in the face of threats of stigma and social and biological death confined to marginalized members of society. This perhaps explains why, although the majority of its members are working class or unemployed, TAC also appeals to HIV-positive middle-class professionals. The organization's appeal has also spread to (HIV-) human rights activists, professionals, and ordinary citizens who see in TAC's leadership and mobilization strategies a heroic and progressive vision of "moral truth" and social justice. Clearly, TAC is able to articulate commonalities across a range of differences in ways that resemble the multiclass, multiethnic, and nonracial composition of the United Democratic Front (UDF), an antiapartheid umbrella organization that emerged in South Africa in the mid-1980s. Notwithstanding the extraordinary successes of TAC, it appears that the majority of HIV-positive South Africans prefer to avoid joining an organization that encourages, if not obliges, its HIVpositive members to publicly disclose their status. This may also explain why relatively few HIV-positive people who use private health care are willing to wear the HIV-positive T-shirt and "out" themselves.

TAC and MSF activists claim that they provide much more than AIDS drugs, condoms, and the promise of a more equitable access to health care. They also provide the possibility of meaning and human dignity for people facing a profoundly stigmatizing and lethal pandemic. To reduce TAC and MSF to a rights-based movement solely concerned with access to health resources underestimates the movement's work at the level of the body, subjectivity, and identity. Neither can mainstream social movement theory account for the powerful ways in which activists with HIV/AIDS make meaning of their terrifying and traumatizing journeys from the shadow of death to "new life." Turner's analysis of the ritual process can illuminate how new HIV statuses, subjectivities, and convictions are rooted and routinized.

\section{SOME CONCLUDING THOUGHTS ON "BIOLOGICAL CITIZENS" AND "RESPONSIBILIZED SUBJECTS"}

Rights-based struggles for health care have increasingly become catalysts for the production of new forms of biomedical citizenship. For example, Adriana Petryna (2002) writes about how, following the Chernobyl disaster, the newly independent Ukrainian state, radiation research clinics, and NGOs "mediated an informal economy of illness and claims" that she refers to as biological citizenship. This new form of citizenship involved selective access to social welfare based on scientific and legal criteria that both acknowledged injury and provided compensation for it. These struggles for biological citizenship unfolded in a context of the failure of the Ukrainian state to address massive unemployment, inflation, and pervasive corruption. Within this context, sufferers became dependent on being able to make "claims for biomedical resources, social equity, and human rights" (Petryna 2002:192). ${ }^{8}$ Similarly, unemployed and poverty-stricken South Africans draw on the scientific language of $\mathrm{CD} 4$ counts and viral loads to gain access to disability grants provided for HIV-positive citizens with CD4 counts below 200. It is also reported that some poor and unemployed citizens are consciously infecting themselves, or threatening to stop treatment, to access this R780 per month disability grant. These are examples of the ways in which, in places such as the Ukraine and South Africa, relationships between citizens and the state are being redefined in the course of life-or-death struggles over access to health care and social welfare. Another example is the TAC's Constitutional Court challenge that compelled the South African Government to provide Nevirapine to pregnant mothers as part of a national PMTCT program.

HIV/AIDS activism in South Africa has also contributed toward new forms of health citizenship (Robins 2004) that are concerned with both rights-based struggles and creating collectively shared meanings of the extreme experiences of illness and stigmatization of individual AIDS sufferers. Drawing on the successes of MSF treatment programs and TAC treatment literacy campaigns in Khayelitsha and Lusikisiki, public health professionals have called for the creation of an empowered citizenry with high levels of understanding of HIV/AIDS issues reinforced by community advocacy and mobilization processes that promote the rights of PWAs. According to David Coetzee and Helen Schneider (2004:1), a "public health revolution" is necessary if ART is to succeed:

\begin{abstract}
Alternative approaches to the traditional management of chronic diseases, such as "directly observed therapy," are needed if the stringent adherence requirements of ART are to be achieved. The evidence from pilot projects is that high levels of adherence stem from "a new kind of contract between providers and clients." The contract is premised on very high levels of understanding, treatment literacy and preparation on the part of users, the establishment of explicit support systems around users, and community advocacy processes that promote the rights of people living with HIV/AIDS. The responsibility for adherence is given to the client within a clear framework of empowerment and support. This is very different to the traditional paternalistic and passive relationship between health care workers and patients-changing this represents the key innovation challenge of an ART programme. [Coetzee and Schneider 2004:72-73]
\end{abstract}

The idea of a "contract" - written or unwrittenbetween providers and clients is not new in the public health field. However, the nature and scale of the 
HIV/AIDS pandemic, along with the requirement of lifelong treatment, reinvigorated calls for a change in the paternalistic culture associated with conventional public health interventions. These calls took place in a context in which it was widely recognized that DOT-TB programs were failing and that South Africa's cure rate of 54 percent has remained "pitifully short of the World Health Organization's goal of 85 percent" (Cape Times 2006). In terms of this call for a paradigm shift, clients would be entitled to free government health care, including ARV drugs, but they would also need to demonstrate that they were "responsibilized clients" specifically through treatment adherence, disclosing their HIV status, using condoms, abstaining from alcohol abuse and smoking, and having healthy diets and lifestyles.

"Responsibilization" also appears in political theorists' writings about contemporary liberal rationalities of government in the United Kingdom and Europe. For example, Andrew Barry and colleagues (1996) use the term to refer to the ways in which, under contemporary versions of liberalism, U.K. citizens are encouraged to "govern themselves." Instead of burdening the National Health Service (NHS), they ought to take care of themselves and become responsible for health issues previously held to be the responsibility of the state. South African public health professionals and activists are calling for something different. They argue that what is needed for HIV/AIDS treatment and prevention programs to succeed is a well-resourced and responsive public sector health system as well as empowered, knowledgeable, and "responsibilized" client-citizens. They are calling for an effective health system together with new forms of community participation and citizenship-what Arjun Appadurai (2002) has described as "auto-governmentality" or "governance from below."

These calls for a "new contract" between clients and providers also resonate with MSF's own ideas about the "responsibilized" citizen-patient. Both draw on the importance of creating empowered HIV-positive identities and nonhierarchical relations between providers and clients, experts, and patients. However, neither of these models of health promotion and rights-based mobilization adequately acknowledges the profoundly traumatic character of illness experiences; neither do they recognize the complex mix of religious, communal, and activist discourses, interpretations, and mediations of these illness experiences. Yet it is precisely the discursive power of these interpretive frames of illness that facilitate the making of new HIVpositive identities and "responsibilized" subjects. Rationalist and liberal individualist conceptions of the "modern subject" and the rights-bearing citizen are inadequate for understanding the transformative character of these new biosocial identities.

Sipho's treatment testimony reveals that AIDS-illness experiences can be narrated in ways that reveal hybrid subjectivities and multiple interpretative frames, including religious, communal, biomedical, and liberal modernist rightsbased discourses. In other words, the "responsibilized" citizen-patient that MSF and progressive public health pro- fessional's desire may not be simply a product of modern, liberal individualist conceptions of the rights-bearing citizen. It is for this reason that Turner's analysis of the ritual process can serve as a useful heuristic device for producing a more complex and nuanced understanding of illness and treatment experiences. Treatment testimonies can provide a view into the social consequences and emancipatory possibilities of this potent triple combination therapy: ARVs, HIV/AIDS activism, and the individual experiences of the passage from "near death" to "new life." Sipho's testimony also reveals how a creative combination of religious, communal, and rights-based responses and interpretations of these traumatic transitions can, under certain conditions, contribute toward the "conversion" of HIV-positive people into both committed activists and "responsibilized" citizens. Finally, the new treatment technologies and moral politics of AIDS have produced collectively shared meanings and new forms of social mobilization and political subjectivity that raise substantial challenges to conventional social movement theories and liberal individualist conceptions of rights, responsibilities, and citizenship.

Steven Robins Department of Sociology and Social Anthropology, University of Stellenbosch, Stellenbosch, South Africa, 7602

\section{NOTES}

Acknowledgments. This article could not have been written without the generous assistance of numerous people, including Phumzile Nywagi, Akhona Ntsaluba, Chris Colvin, Andrew Boulle, Jean Comaroff, Lauren Muller, Leslie Swartz, K. Ruth Cornick, Herman Reuter, Kees van der Waal, and numerous other TAC and MSF activists. I would also like to thank John Gaventa, Melissa Leach, Ian Scoones, Bettina von Lieres, and other participants in the joint School of Government, University of the Western Cape, and Institute for Development Studies project on Citizenship, Participation and Accountability. I am particularly indebted to Brahm Fleisch for his suggestion that I turn to Turner's analysis of ritual processes. I am also especially grateful to Melissa Leach and Chris Colvin for exceptionally helpful comments on drafts of this article. Finally, thanks go to the $A A$ reviewers for their constructive comments. A previous draft of this article appeared as a working paper at the Wits Institute for Social and Economic Research (WISER) Symposium on "Life and Death in a Time of AIDS: The South African Experience," Witwatersrand University, October 14-16, 2004.

1. Yesterday is set in the AIDS-ravaged rural areas of KwaZulu-Natal, one of the regions of South Africa that has been most devastated by the pandemic. Infection rates for young black women are in the vicinity of 30 percent. Current estimates put the figure of HIVpositive South Africans at between five to six million.

2. In a moving cinematic depiction of AIDS stigma, isolation, and death, the film shows the ex-miner breaking down as he tells his HIV-positive wife about how his fellow workers avoided him because there were no toilets underground and his diarrhea was out of control. He cries uncontrollably as he tells his wife how his pants were regularly caked in excrement.

3. This study is based on 15 interviews done in 2002 and 2004.

4. The study resonates with Melissa Leach's observations, based on her ethnographic work on MMR vaccination controversies in the United Kingdom, that it is often simply the strength of shared experiences - of having children who they believe have become ill because of exposure to the vaccination-that produces the motivation and commitment to participate in these social movements 
(Leach, personal correspondence, November 22, 2004). These anthropological studies draw attention to the relationship between participation in illness-based movements and transformations in subjectivities, identities, and social commitments.

5. For a detailed history of TAC, see Robins (2004); Friedman and Mottiar (2004); and "Treatment Action: An Overview, 1998-2001," at www.tac.org.za.

6. Patients usually go onto ART when their CD4 count is below 200.

7. New social movement (NSM) theorists and activists have also been criticized for being more concerned with questions of cultural recognition, difference, and identity than with challenging global structures of social inequality. Edelman (2001), for example, criticizes NSM theorists for uncritically celebrating and festishizing identity and difference in ways that end up reproducing the fragmentation of popular struggles against global capital and its allies. These criticisms of social movements have been relatively mild and muted compared to recent critiques that slate NGOs as unaccountable and undemocratic handmaidens of neoliberalism and global capital (see Hardt and Negri 2000).

8. Vinh-Kim Nguyen (2005:126) uses the concept of "therapeutic citizenship" to describe everyday practices and techniques that produce new kinds of subjects and forms of life-AIDS activists, resistant viruses, and therapeutic citizens. For example, Nguyen writes about African HIV/AIDS activists who use their activist networks to get invited to European HIV/AIDS conferences so that they can access ARVs; in many cases they remain in Europe to stay on treatment. For these activists, access to treatment depends on developing social relations and capitalizing on social networks (Nguyen 2005:133). Nguyen's notions of "therapeutic citizenship" also refers to how HIV/AIDS has been able to "stitch together such apparently disparate phenomena as condom demonstrations, CD4 counts, sexual empowerment, retroviral genotyping, an ethic of sexual responsibility, and compliance with complex drug regimens, into a remarkably stable worldwide formation" (2005:126). As Nguyen puts it, "therapeutic citizenship is a biopolitical citizenship, a system of claims and ethical projects that arise out of the conjunction of techniques used to govern populations and manage individual bodies" (2005:126).

\section{REFERENCES CITED}

Agamben, Giorgio

1998 Homo Sacer. Daniel Heller-Roazen, trans. Stanford: Stanford University Press.

Alvarez, S. E., E. Dagnino, and A. Escobar, eds.

1998 Cultures of Politics/Politics of Cultures: Re-Visioning Latin American Social Movements. Boulder, CO: Westview Press.

Appadurai, Arjun

2002 Deep Democracy: Urban Governmentality and the Horizon of Politics. Public Culture 14(1):21-47.

Arendt, Hannah

1958 The Human Condition. Chicago: University of Chicago Press.

Barry, Andrew, Thomas Osborne, and Nikolas Rose, eds.

1996 Foucault and Practical Reason: Liberalism, Neo-Liberalism and Rationalities of Government. London: University College London.

Bastos, Christiana

1999 Global Responses to AIDS: Science in Emergency. Bloomington: Indiana University Press.

Beck, Ulrich

1992 Risk Society: Towards a New Modernity. New Delhi: Sage. Biehl, João

2001 Vita: Life in a Zone of Social Abandonment. Social Text 19(3):131-149.

2004 The Activist State: Global Pharmaceuticals, AIDS and Citizenship in Brazil. Social Text 22(3):105-132.

Cameron, Edwin

2005 Witness to AIDS. Cape Town: Tafelberg.

Cape Times

2005 Trade-offs Needed in ARV Roll Out: Solly Benatar. Cape Times, April 15:5.
2006 Multi-drug Resistance TB Increases in SA. Cape Times, March 24:8.

Coetzee, David, and Helen Schneider

2004 Editorial. South African Medical Journal 93(10):1-3.

Cohen, Robin, and Shirin M. Rai, eds.

2000 Introduction. In Global Social Movements. Pp. 1-17. London: Athlone Press.

Comaroff, Jean

2005 Beyond the Politics of Bare Life: AIDS and the Neoliberal Order. Paper presented at the Berlin symposium on "AIDS and the Moral Order," March 3-6, Berlin.

Denzin, Norman K.

1987 The Recovering Alcoholic. London: Sage.

Edelman, Marc

1999 Peasants against Globalization: Rural Social Movements in Costa Rica. Stanford, CA: Stanford University Press.

2001 Social Movements: Changing Paradigms and Forms of Politics. Annual Review of Anthropology 30:285-317.

Epstein, Steven

1996 Impure Science: AIDS, Activism, and the Politics of Knowledge. Berkeley: University of California Press.

Escobar, Arturo, and Sonya E. Alvarez

1992 The Making of Social Movements in Latin America: Identity Strategy and Democracy. Boulder, CO: Westview Press.

Farmer, Paul

2004 An Anthropology of Structural Violence. Current Anthropology 45(3):305.

Friedman, Steven, and Shauna Mottiar

2004 Rewarding Engagement? The Treatment Action Campaign and the Politics of HIV/AIDS. Centre for Civil Society:1-42. Electronic document, http://www.nu.ac.za/ccs/ files/FRIEDMAN\%20MOTTIER\%20A\%20MORAL\%20TO\%20 THE\%20TALE\%20LONG\%20VERSION.PDF, accessed January $16,2006$.

Giddens, Anthony

1991 Modernity and Self-Identity: Self and Society in the Late Modern Age. Cambridge: Polity Press.

Hardt, Michael, and Antonio Negri

2000 Empire. Cambridge, MA: Harvard University Press.

Irwin, A.

1995 Citizen Science: A Study of People, Expertise and Sustainable Development. London: Routledge.

Kistner, Ulrike

N.d. Sovereign Power and Bare Life with HIV/AIDS: Bio-Politics South African Style. Electronic document, http://wiserweb.wits.ac.za/PDF\%20Files/biopolitics\%20\%20kirstner, accessed October 20, 2004.

Laclau, Ernesto, and Chantal Mouffe

1985 Hegemony and Socialist Strategy: Towards a Radical Democratic Politics. London: Verso Books.

Latour, Bruno

1993 We Have Never Been Modern. Cambridge, MA: Harvard University Press.

Leach, Melissa, Ian Scoones, and Brian Wynne, eds.

2005 Science and Citizens: Globalization and the Challenge of Engagement. London: ZED Press.

Levi, Primo

1979 The Drowned and the Saved. In If This Is Man: The Truce. London: Penguin Books.

Melucci, Alberto

1989 Nomads of the Present: Social Movements and Individual Needs in Contemporary Society. Philadelphia: Temple University Press.

Nguyen, Vihn-Kim

2005 Antiretrovirals, Globalism, Biopolitics and Therapeutic Citizenship. In Global Assemblages: Technology, Politics and Ethics as Anthropological Problems. Aihwa Ong and Stephen Collier, eds. Pp. 124-144. London: Blackwell.

Olsen, $\mathrm{M}$.

1965 The Logic of Collective Action: Public Goods and the Theory of Groups. Cambridge, MA: Harvard University Press.

Petryna, A.

2002 Life Exposed: Biological Citizens after Chernobyl. Princeton: Princeton University Press. 
Robins, Steven

2004 "Long Live Zackie, Long Live": AIDS Activism, Science and Citizenship after Apartheid. Journal of Southern African Studies 30(3):651-672.

2005a AIDS, Science and Citizenship after Apartheid. In Science and Citizens: Globalisation and the Challenge of Engagement. M. Leach, I. Scoones, and B. Wynne, eds. Pp. 13-30. London: Zed Press.

2005b From "Medical Miracles" to "Normal(ised) Medicine": AIDs Treatment, Activism and Citizenship in the U.K. and South Africa. IDS Working Paper 252. Institute for Development Studies at the University of Sussex, U.K.

Smelser, N. J.

1962 Theory of Collective Behavior. New York: Free Press.
Touraine, A.

1981 The Voice and the Eye: An Analysis of Social Movements. Cambridge: Cambridge University Press.

1985 An Introduction to the Study of New Social Movements. Social Research 52(4):749-787.

Turner, Victor

1961 Ndembu Divination: Its Symbolism and Techniques. Manchester: Manchester University Press.

1969 The Ritual Process: Structure and Anti-Structure. Chicago: Aldine.

Van Gennep, Arnold

1960 The Rites of Passage. Monika B. Vizedom and Gabrielle L. Caffee, trans. London: Routledge and Kegan Paul. 